„AFRYKA”, nr 50, 2019

LUCJAN BUCHALIK

https://doi.org/10.32690/AFR50.2

\title{
BATWA - STO LAT PRZEMIAN. MIĘDZY GLOBALIZACJĄ, PAŃSTWEM A TURYSTYKĄ
}

\begin{abstract}
Streszczenie
Artykuł jest głęboką refleksją nad zmianami zachodzącymi w kulturach grup mniejszościowych, nie tylko w kontakcie z ich większymi sąsiadami, lecz także, i przede wszystkim, pod wpływem procesów globalizacji i dynamicznie rozwijającej się turystyki. Forma badań pozwala zaprezentować lud Batwa żyjący w regionie Wielkich Jezior Afrykańskich z szerszej perspektywy czasowej. Zestawienie dwóch okresów badawczych, jednego z początku XX wieku (Jan Czekanowski), a drugiego z wieku XXI (Lucjan Buchalik) umożliwiło prześledzenie zmian w codziennym życiu tej grupy. Z jednej strony, Batwa są marginalizowani, a z drugiej absorbowani przez otaczające ich, dominujące ludy. Badając proces transformacji, zauważyć można, że Batwa zaakceptowali wiele zmian wynikających z kontaktów ze światem zewnętrznym. To proces przymusowego wysiedlenia $\mathrm{z}$ ich rodzimych terenów zagroził istnieniu tej wspólnoty.
\end{abstract}

Słowa kluczowe: Jan Czekanowski, Batwa, zmiany w kulturze (proces przemian), rolnictwo, autochtoni

Badania nad wpływem turystyki rozpocząłem w pierwszej dekadzie XXI wieku na przykładzie ludów Dogon (Mali), Tamberma (Togo) i Somba (Benin). Według jednej z pierwszych wysuniętych przeze mnie hipotez, Dogonowie klasyfikowani jako społeczność segmentarna lepiej wykorzystują turystykę do własnych celów niż Tamberma i Somba uważani za społeczności acefaliczne1. W związku z przygotowywaną w Muzeum Miejskim w Żorach wystawą „Polskie poznawanie świata" pojawiła się możliwość wyjazdu do Ugandy. Wykorzystałem tę sytuację do przeprowadzenia badań wśród - uważanych również za społeczność acefaliczną - Batwa, opisywanych w literaturze polskiej przez profesora Jana Czekanowskie-

${ }^{1}$ Organizację społeczną tej grupy ludów opisują Albert-Marie Maurice (Atakora, Otiau Otammari Osuri. Peuple du Nord Bénin, Paris: Académie des Sciences d'Outre-Mer 1950) oraz Paul Mercier (Tradition changement historie: les 'Somba'du Dahomey septentrional, Paris: Éd. Anthropos 1968). 
go (1882-1965). Badacz po zakończeniu studiów w Zurychu i obronie doktoratu rozpoczął pracę w Królewskim Muzeum Ludoznawczym w Berlinie, a w 1907 r. wziął udział w niemieckiej wyprawie naukowej organizowanej przez księcia meklemburskiego Adolfa Fryderyka w rejon Międzyjezierza Afrykańskiego i lasów Aruwimi (1907-1909)2.

Do badań muzealnych wybraliśmy odcinek, na którym od grudnia 1907 do lutego 1908 r. prowadził badania profesor. Są to tereny rozpościerające się od Katwe (Jez. Edwarda), przez wschodnie stoki masywu górskiego Ruwenzori (Rwenzori) do Fort Portal, następnie wzdłuż rzeki Semliki (Semuliki) aż do Ntoroko nad Jez. Alberta. Pigmejów spodziewałem się spotkać w okolicach rzeki Semliki oraz w okolicy Bwindi, gdzie mieszkają Batwa. Gromadzenie eksponatów, które było głównym celem wyjazdu, było doskonałą okazją do obserwacji etnologicznych pozwalających uchwycić proces przemian zachodzących wśród ludów niskorosłych, na terenach opisywanych przez profesora Czekanowskiego ${ }^{4}$.

\section{Pigmeje i Pigmoidzi}

Ludy niskorosłe zamieszkujące Afrykę od drugiej połowy XIX w. absorbowały uwagę europejskich naukowców5 ${ }^{5}$ W latach 30. XX wieku prof. Tadeusz Henzel

2 J. Czekanowski Verwandtschaaftsbeziehungen der zentralafrikanischen Pygmäen. „Korrespondenz-Blatt der Deutschen Gesellscaft für Anthropologie, Ethnologie und Urgeschichte", nr 9/12, 1910; Forschungen im Nil-Kongo-Zwischengebiet, t. II Ethnografie. Uele/ Ituri/ Nil-Länder, Lepzig: Klinkhardt \& Biermann 1924; W głąb lasów Aruwimi, Wrocław: Polskie Towarzystwo Ludoznawcze 1958; Struktura etniczna Afryki a nawarstwienia najmtodsze, „Lud” t. 45, 1960, ss. 13-34; Dziennik podróży afrykańskiej, Warszawa: Polskie Towarzystwo Afrykanistyczne 2014. Wielu cytowanych w niniejszym artykule naukowców prowadziło badania na początku XX wieku, autor korzystał z ich prac wydanych później.

${ }^{3}$ W literaturze polskiej dominuje zapis „Ruwenzori”, „Semliki”, współcześnie w Ugandzie w jęz. angielskim - stosuje się zapis „Rwenzori” i ,Semuliki”. Podając nazwy w języku angielskim będę stosował powyższy zapis, np.: Semuliki National Park.

${ }^{4}$ Prowadzenie badań było też okazją do porównania sposobów pracy etnologów z początku XX w. i początków XXI w., cennych informacji w tej materii dostarcza jego Dziennik podróży afrykańskiej. Wyjazd był zorganizowany przez wspomniane Muzeum przy wydatnej pomocy Stowarzyszenia Edukacja dla Pokoju z Warszawy. W tym miejscu pragnę podziękować Piotrowi Boruszkowskiemu za udzieloną pomoc.

${ }^{5}$ Pierwsze wzmianki o Pigmejach pochodzą ze starożytnego Egiptu. Na dworze faraona Pepi II (III tysiąclecie p.n.e.), przebywał Pigmej dostarczony przez Harchufa, gubernatora Asuanu. Przedstawienie Pigmeja można znaleźć także na egipskiej ceramice. W czasach współczesnych, niemiecki botanik Georg Schweinfurth, przybywający do Ituri (dorzecze Konga) w 1869 r. był pierwszym Europejczykiem, który zobaczył i napisał o Mbuti (Im Herzen von Afrika, Leipzig 1874). W latach 30. XX w. jezuicki misjonarz Paul Schebesta (uważany za najwybitniejszego znawcę tematu) podjął pierwsze badania antropologiczne mieszkańców Ituri. Od tego czasu antropologowie zachodni zainteresowali się ludami niskorosłymi środkowej Afryki. 
pisał, że Pigmeje „stanowią jeden z bardzo aktualnych problemów współczesnej antropologii" ${ }^{\circ}$. Zwracano uwagę przede wszystkim na ich niski wzrost, dlatego też zaczęto ich łączyć z innymi ludami niskorosłymi, głównie zamieszkującymi Azję. Pod koniec XIX w. uważano, że stanowią oni jednolitą rasę, będącą początkowym stadium ludzkości ${ }^{7}$. Wtedy też upowszechniła się nazwa Pigmeje, nawiązująca do greckiego pygmaíos - mały jak pięść ${ }^{8}$. Później dokonano podziału na autentycznych Pigmejów i mieszańców nazywanych Pigmoidami ${ }^{9}$. Miał w tym swój udział profesor Jan Czekanowski dokonując morfologicznej analizy antropologicznej lu$\mathrm{du}^{10}$. Innym efektem jego badań było określenie nazw, jakimi poszczególne grupy Pigmejów wzajemnie się nazywały ${ }^{11}$.

Badania wśród Pigmejów Czekanowski rozpoczął od wizyty u Batwa w grudniu 1907 r., w pobliżu Nyundo (Rwanda), kiedy przebywał przez kilka tygodni w gościnie u Ojców Białych ${ }^{12}$. Jak ważne były badania nad Pigmejami dla profesora, może świadczyć zapis w jego książce „Środa, 15 stycznia. Był to najważniejszy dzień ze wszystkich dotychczas przeze mnie spędzonych w głębi Czarnego Lądu. (...) zjawili się dwaj goście: jeden to $\mathrm{z}$ dawna oczekiwany Pigmej, (..."'13. Widocznie odwiedzani wcześniej Batwa, nie są uważani za „klasycznych” Pigmejów - nie zrobili na nim takiego wrażenia. Jeszcze w połowie XX w. uważano, że

Najbardziej rasowymi pigmejami (LB: oryginalna pisownia) w Afryce są Bambuti, największa zwarta grupa prawdziwych pigmejów w lasach dorzecza Ituri, prawobrzeżnego dopływu rzeki Kongo. Jest ich około 35 tysięcy. Dalsze ich resztki żyją rozsiane w Gabonie i Kamerunie. (...) Poza Bambutami, którzy posiadają wszelkie cechy prawdziwych pigmejów, wałęsają się pigmoidzi Batwa na stokach wulkanów koło jeziora Kivu i w Ruandzie (około 7 tysięcy), i znacznie silniejsza grupa (około 100 tysięcy)

${ }^{6}$ T. Henzel, Pigmeje Centralno-Afrykańscy, Lwów: Towarzystwo Naukowe 1934.

7 Przyczyniły się do tego głównie prace Paula du Chaillu (1831-1903) francusko-amerykańskiego podróżnika, zoologa i antropologa (L'Afrique Sauvage, Paris 1868), wspomnianego już Georga Schweinfurtha (1836-1925) i Armanda de Quatrefagesa (1810-92) zwanego ojcem badaczy Pigmejów (Les Pygmées, Paris 1887).

${ }^{8}$ Używanie w niniejszym artykule terminu Pigmej jest swego rodzaju skrótem myślowym odnoszącym się zarówno do ludzkiej fizyczności jak i do pewnej specyficznej treści etnologicznej.

${ }^{9}$ Kryterium podziału stał się przeciętny wzrost mężczyzn, ludy mające ponad $150 \mathrm{~cm}$ wzrostu zaliczane zostały do Pigmeoidów, poniżej $150 \mathrm{~cm}$ do Pigmejów. T Henzel (1905-55) - antropolog z Uniwersytetu Jana Kazimierza we Lwowie - uważał, że „problem tzw. 'pigmoidów' wiąże się ściśle z zagadnieniem Pigmejów; uważa się ich bowiem powszechnie za formę powstałą z wykrzyżowania Pigmejów z niepigmejską ludnością murzyńską" (T. Henzel, Pigmeje...op. cit., s. 11).

${ }^{10}$ J. Czekanowski, Verwandtschaaftsbeziehungen ... op. cit.

${ }^{11}$ J. Czekanowski, Forschungen ...op. cit.

${ }^{12}$ Misja Ojców Białych w Nyundo (ok. 12 km na wschód od Gisenyi, północno-wschodni brzeg Jez. Kivu) została założona w 1901 r., była to pierwsza misja katolicka na terenie Rwandy, poważnie uszkodzona w czasie I wojny światowej (https://en.wikipedia.org/wiki/Nyundo,_Rubavu, dostęp 29.06.2016).

13 J. Czekanowski, W głą ...op. cit., s. 194. 
pigmoidów Baćwa (Batśwa), (...) między rzekami Ubangi i Dża ciągną się siedziby pigmoidów Babinga ${ }^{14}$.

Czytając opisy Jana Czekanowskiego można odnieść wrażenie, że różnica między Pigmejami i Pigmoidami dotyczy głównie wzrostu, a nie kultury. Dlatego, mimo iż moje obserwacje dotyczą Pigmoidów Batwa, w niniejszym opracowaniu korzystam także z opisów dotyczących „klasycznych” Pigmejów ${ }^{15}$.

Pigmeje charakteryzują się niskim wzrostem, wahającym się od 140 do $150 \mathrm{~cm}$. Sądzę że obecnie/aktualnie więcej jest Pigmoidów niż samych Pigmejów. Według Colina M. Turnbulla ${ }^{16}$ :

Większość Pigmejów - oprócz różnicy wzrostu - różni się od Murzynów jeszcze innymi cechami: ich nogi są krótkie w stosunku do tułowia, są silni, muskularni, mają zwykle wykrzywione plecy, głowy okrągłe, oczy szeroko rozstawione, nosy płaskie i prawie tak szerokie jak usta. Włosy rosną im na głowie pęczkami, a ciało pokryte jest niekiedy gęstym włosem od stóp do głów. Inną cechą charakterystyczną jest czujny wyraz twarzy, bezpośredni i nielękliwy, tak bystry, jak żywe są poruszenia zręcznego i zwinnego ciała ${ }^{17}$.

Współcześnie Batwa są coraz wyżsi ${ }^{18}$, jest to efekt przede wszystkim mieszanych małżeństw, ale także zmiany diety. W czasie wizyty w zagrodzie pani Nory w Bwindi mogłem zauważyć, że pokolenie dziadków jest niskorosłe, natomiast najmłodsze pokolenie jest średniego wzrostu i niczym nie odróżnia się od sąsiadów Bantu. Na różnicę w średniej wzrostu jako skutku odmiennej, bogatszej diety zwracali także uwagę austriaccy etnolodzy prowadzący badania wśród Kurumbów zamieszkujących północną część Burkiny Faso ${ }^{19}$. Zauważyli, że dwa najważniejsze rody Konfe i Sawadogo (trudniące się oprócz rolnictwa także myślistwem) są wyższe od pozostałych rodów trudniących się tylko rolnictwem. Współcześnie, kiedy dieta pozostałych rodów została wzbogacona, średnia wzrostu uległa wyrównaniu. Pewne różnice są widoczne tylko wśród najstarszej generacji. Na zmiany w różnicy wzrostu zwracali także uwagę sami Kurumbowie. Zjawisko to

${ }_{14}$ Zachowano oryginalną pisownię. S. Łysik, Pigmeje afrykańscy i zagadnienie ich języka, „Lud” t. 45, 1960, s. 42.

${ }_{15}$ Dotyczy to tak prac J. Czekanowskiego, C. M. Turnbulla jak i relacji misjonarzy czy turystów.

${ }^{16}$ Colin M. Turnbull (1924-94), brytyjsko-amerykański antropolog i etnomuzykolog, znawca problemów socjalnych i cywilizacyjnych Afryki, od lat 50. XX w. prowadził badania terenowe wśród Pigmejów w Demokratycznej Republice Konga (rejon Ituri) oraz Ików w Ugandzie.

${ }_{17}$ C. M. Turnbull, Leśni ludzie, Warszawa: Iskry 1967, s. 28.

18 Podobne zjawisko zauważył J. Łapott u Gagou na Wybrzeżu Kości Słoniowej (J. Łapott, Wyprawa Naukowa SAHEL'87 - sprawozdanie z przebiegu i wyników działalności etnologicznej ekspedycji do Afryki, „Materiały Zachodnio-Pomorskie” t. 37, 1991, s. 302-303).

19 A.-M. Schweeger-Hefel, W. Staude, Die Kurumba von Lurum, Wien 1972. 
wymaga jednak dalszych badań, oparte jest bowiem głównie na obserwacjach etnologicznych i wywiadach autora artykułu.

Termin twa jest używany w wielu językach Bantu, chociaż według niektórych badaczy jest to pierwiastek pigmejski ${ }^{20}$. Określa on ludzi, którzy są myśliwymi-zbieraczami, pierwotnymi mieszkańcami lasów tropikalnych, mającymi bardzo niski status społeczny. Współcześnie pojęcie twa jest dość szeroko stosowane do określenia Pigmejów środkowej Afryki, Buszmenów w południowej Afryce i innych zbieraczy w pozostałych częściach Afryki. Tłumaczenie terminu twa jako „Pigmej” jest nieprecyzyjne bowiem, w myśl zachodniej koncepcji, Pigmeje to niscy ludzie lasu. Pojęcie twa pojawia się w etnonimie Batwa, sugerując, że jest to populacja Pigmejów, jednak z punktu widzenia antropologii fizycznej Batwa różnią się od nich. Przedstawiciele tego ludu zamieszkujący poza dżunglą są nieco wyżsi niż „klasyczni” Pigmeje, można też zauważyć niewielkie różnice w wyglądzie fizycznym, dlatego też są oni traktowani jako Pigmoidzi. Stąd też dystans Czekanowskiego do traktowania ich jako Pigmejów i duża radość ze spotkania pierwszego „prawdziwego” Pigmeja 15 stycznia 1908 r. w Fort Portal. J. Czekanowski wyraźnie rozróżniał Batwa od Pigmejów zamieszkujących na północ od Ruwenzori dorzecze Ituri i określanych przez wielu autorów etnonimem Bambuti ${ }^{21}$.

W czasie kiedy Czekanowski prowadził swoje studia w Afryce, wiedza o Pigmejach była niewielka. Profesor jest uważany za jednego z pierwszych naukowców, którzy prowadzili wśród nich badania terenowe. Dopiero później zakrojone na większą skalę obserwacje prowadził pochodzący ze Śląska (Pietrowice Wielkie) Paul Schebesta ${ }^{22}$. Duże zasługi dla naukowego zbadania Pigmejów miał Wilhelm Schmidt ${ }^{23}$. Wśród wybitnych badaczy tych ludów należy również wymienić Colina M. Turnbulla. W Polsce pierwsze większe opracowanie na ten temat ukazało

${ }^{20}$ S. Łysik, Pigmeje...op. cit., s. 43.

${ }^{21}$ Nazwą „Bambuti” P. Schebesta chciał ,oznaczać wyłącznie prawdziwych pigmejów (LB: oryginalna pisownia) w Kongo Belgijskim" (S. Łysik, Pigmeje ...op. cit., s. 44).

22 Ks. Paul Schebesta (1887-1967), pochodzący ze Śląska niemiecki misjonarz, etnograf. członek wiedeńskiego Instytutu Antropologicznego, prowadził badania głównie wśród Pigmejów w Afryce Środkowej. Badania wśród Pigmejów znad Iturii rozpoczął w latach 1929-30, ponownie wrócił tam w latach 1934-35, badania wtedy prowadzone dotyczyły głównie ogólnego obrazu tej populacji. W czasie kolejnych wypraw (1949-50 i 1954-55) jego zainteresowania naukowe koncentrowały się wokół problemów językowych. Prowadził również badania na Filipinach (1938-39) i Malezji (1924-25). Szerzej postać tę przedstawia S. Łysik w artykule zamieszczonym na łamach „Ludu” (Pawet Schebesta - pionierski badacz Pigmejów (1887-1967), „Lud” t. 53, 1969, ss. 251272). W ostatnich latach postać tę popularyzuje ks. prof. Jacek J. Pawlik dzięki przygotowanej przez Koło Naukowe Antropologii Kultury Wydziału Teologii Uniwersytetu Warmińsko-Mazurskiego w Olsztynie pt. „O. Paul Joachim Schebesta SVD (1887-1967), pionier badań wśród Pigmejów i Negrytów".

${ }^{23}$ Ks. Wilhelm Schmidt (1868-1954), austriacki werbista, wybitny lingwista, antropolog i etnolog, nigdy nie prowadził badań terenowych wśród Pigmejów, wnikliwy teoretyk i syntetyk. 
się w latach 20. XX w. ${ }^{24}$, chociaż wzmianki w literaturze fachowej zdarzały się już wcześniej ${ }^{25}$.

\section{Batwa}

Batwa ${ }^{26}$ są przedstawicielami jednego z kilku afrykańskich ludów koczowniczych. Zamieszkują region Wielkich Jezior Afrykańskich (Uganda, Rwanda, Burundi, Demokratyczna Republika Konga). Podstawą ich gospodarki jest myślistwo i zbieractwo. Żyją we współzależności z rolnikami Bantu, którym dostarczają mięso w zamian za produkty rolne. Dawniej mieszkali w puszczy, w małych grupach liczących do 50 osób, tworząc odrębne społeczności i nie posiadając scentralizowanej władzy ${ }^{27}$. Dzisiaj osiedleni, również mieszkają w małych skupiskach, żyjąc najczęściej we wsiach rolników lub w ich pobliżu. Dlatego traktuje się ich często jako jedną z grup ludów Bantu. Las był ich domem i zaopatrywał ich w środki niezbędne do życia, dlatego byli zwani „strażnikami lasu”. Tam też znajdowały się ich miejsca kultu. Szacuje się, że liczebność Batwa mieści się w przedziale od 86000 do 112000 osób, co czyni ich mniejszością w krajach zamieszkania.

Na początku XX w. „Pigmeje lasów dziewiczych Afryki środkowej” ${ }^{28}$ oraz Buszmeni byli zaliczani do tej samej archaicznej warstwy kulturowej. Posiadali „prymitywną kulturę” i prowadzili podobny myśliwsko-zbieracki tryb życia. Różnili się od otaczających ich „Murzynów jaśniejszymi odcieniami barwy skóry”29. Uważano ich za ludność autochtoniczną środkowej Afryki ${ }^{30}$. Pigmeje i Pigmoidzi w przeważającej większości prowadzili koczowniczy tryb życia, z tego też powodu nie budowali stałych domostw. Zadawalali się prostymi szałasami wykonanymi z gałęzi i liści, a ich wyposażenie w sprzęty domowe było bardzo skromne. Pożywienie pozyskiwali w puszczy, mężczyźni zajmowali się myślistwem, a kobiety zbieractwem. Podstawową bronią był mały łuk i zatrute strzały oraz oszczepy. Podstawą diety były jednak produkty roślinne znajdywane w lesie, pozyskiwane drogą

${ }^{24}$ E. Kosibowicz, Problem ludów pigmejskich, Kraków: Wydawnictwo Księży Jezuitów 1927.

${ }^{25}$ Przykładem może być rocznik Lud: t. 10, s. 339; t. 18, s. 20; t. 23, s. 48, 178; t. 27, s. 159 , 160. W literaturze polskiej autorem pierwszej wzmianki o Pigmejach jest ks. B. Chmielewski, którą zamieścił w pracy Nowe Ateny albo Akademia Wszelkiey Scyencyi Pelna (pierwsze wydanie Lwów 1745-46).

${ }^{26}$ Terminu Batwa używa się na określenie grupy, a jednostka zwana jest Mutwa (1.p.), w literaturze używa się także terminów Twa, Abatwa, Butwa.

${ }^{27}$ Według M. C. Turnbulla, Batwa „(...) nie lubią i unikają przejawów osobistego autorytetu, choć w żadnym wypadku nie są pozbawieni zmysłu odpowiedzialności. Uważają, że jest ona sprawą całej grupy”. Na pytanie, dlaczego nie mają wodzów odpowiadają: „dlatego, że jesteśmy ludźmi lasu" (C. M. Turnbull, Leśni ...op. cit., s. 123-124).

${ }_{28}$ J. Czekanowski, Struktura etniczna ...op. cit., s. 19.

${ }^{29}$ Ibidem.

${ }^{30}$ Ibidem. 
wymiany z rolnikami. Dawniej uważano, że ze względu na niski poziom rozwoju gospodarczego Pigmeje stanowią najniższy stopień kultury ludzkości. Różnili się od ludów Bantu pod względem gospodarczym, społecznym i religijnym ${ }^{31}$. Batwa nie używają własnego języka, posługują się kilkoma językami swoich sąsiadów (ludów Bantu) ${ }^{32}$, określa się ich też różnymi etnonimami, lecz mimo to, uznaje się, że mają wspólną tożsamośćc 33 .

Z punktu widzenia antropologii fizycznej Batwa są populacją heterogeniczną, w której obok elementów pigmejskich występują cechy rasowe otaczającej ich niepigmejskiej ludności murzyńskiej, co udowodnił Jan Czekanowski dzięki morfologicznej analizie antropologicznej. Jego uczeń Henzel uważa, że:

Batwa reprezentują szczątkową, najbardziej na wschód wysuniętą grupę szczepów tej nazwy. Grupa ta zamieszkuje enklawę lasów centr.-afr. (oryginalny zapis) na terytorium Ruandy, stanowiącą szczątek dawnych lasów Ruandy, które zniszczone zostały przez systematyczną ekspansję ludności rolniczej, dążącej do zdobycia nowych obszarów pod uprawę. Nieustanna ekspansja ludności rolniczej doprowadziła do wyniszczenia lasów, które zachowały się jedynie w okolicach górzystych (w górach wulkanów Kivu), i podcięła byt myśliwskich plemion Batwa, tak że część ich nie mogąc utrzymać się w kurczącym się stale lesie, osiedliła się w okolicy Niansy; ci osiedleni Batwa zajmują się przeważnie garncarstwem, czarownictwem, względnie pełnią służbę nadwornych myśliwych, nie przechodzą jednak nigdy do uprawy roli3i ${ }^{34}$.

Dotarcie - nawet na początku XXI w. - do Batwa nie jest proste. Nie ze względu na niedostępność zamieszkałego przez nich terenu, czy też złej sieci dróg, ale ze względu na brak informacji na ich temat. Poszczególne rodziny tej grupy mieszkają w wioskach zdominowanych przez rolników Bantu. Z jednej strony są marginalizowani (stąd „zmowa milczenia” wokół tematu pigmejskiego), a z drugiej wchłaniani przez otaczające ich ludy dominujące. Jest to proces znany i występujący na wielu obszarach świata, opisany przez francuskiego etnologa Jean-Loup Amselle'a ${ }^{35}$.

${ }^{31}$ S. Łysik, Pigmeje ... op. cit., s. 46-47.

32 Już pierwsi badacze Pigmejów w II połowie XIX w. zwracali uwagę, że „ludy karłowate posługują się językami swych wysokorosłych sąsiadów” (S. Łysik, Pigmeje ... dz. cyt, s. 49). W połowie XX w. dyskutowano nad istnieniem języka pigmejskiego. Przyjmowano, że skoro istnieje osobna rasa pigmejska - tak wtedy uważano - powinien też istnieć osobny język. Kwestią wyjaśniania problemu języka pigmejskiego zajmował się głównie P. Schebesta, uchodzący za specjalistę w tej materii (S. Łysik, Pigmeje ..., op. cit. s. 47-49).

33 http://kwekudee-tripdownmemorylane.blogspot.com/2013/03/batwa-people-one-of-first-people-on.html, dostęp 04.08.2014.

34 T. Henzel, Pigmeje... op. cit. s. 12.

35 J.-L. Amselle, 1999, Ethnies et espaces: pour une anthropologie topologique, (w:) J.-L. Amsel, E. M'Bokolo (red.), Au coeur de l'ethnie: ethnie, tribalisme et État en Afrique, Paris 1999, s. $14-29$. 
Odwiedziłem w Bwindi zagrodę pani Nory ${ }^{36} \mathrm{z}$ ludu Batwa, sąsiadującą z zagrodą zamieszkałą przez rodzinę, której głową jest pan John. Informacji o zagrodzie i rodzinie udzielała jednak jej seniorka - pani Nora. W tradycyjnym społeczeństwie Batwa, a także wśród Pigmejów znad Ituri, panowało równouprawnienie. „Kobieta może brać udział w dyskusjach między mężczyznami, jeśli ma coś do powiedzenia na dany temat" ${ }^{37}$ - pisali badacze. Zwracano uwagę, ze niejednokrotnie kobieta kieruje rodziną, jest silną i władczą matką rodu ${ }^{38}$. Podobnie jest dzisiaj. Taką osobą jest pani Nora, która po śmierci męża została głową rodziny. W czasie mojej wizyty grała pierwsze skrzypce, to ona podejmowała decyzje, kto będzie rozmawiał, kto będzie tańczył i czy coś sprzedadzą obcym ${ }^{39}$.

\section{Zmiany w kulturze}

Już Jan Czekanowski na początku XX wieku zauważył, że ludy niskorosłe uległy „głębokiemu przeobrażeniu kulturowemu pod wpływem swoich sąsiadów” ${ }^{40}$. Na problem zmian a właściwie zaniku tradycyjnej kultury Pigmejów zwracał też uwagę P. Schebesta. W 1930 r. opracował on plan zmiany ich trybu życia z koczowniczego na osiadły i namawiał ich do uprawy bananów. W jego przekonaniu był to plan niezbędny do uratowania zanikającej kultury tego ludu ${ }^{41}$. Można $z$ tego wyciągnąć wniosek, że dla P. Schebesty zmiany w kulturze materialnej, przejście od gospodarki zbieracko-łowieckiej do rolnictwa, z życia koczowniczego do osiadłego były nieistotne. Ważniejsze dla etnografa było zachowanie przez badane ludy ich unikalnej kultury duchowej. Na proces zachodzących zmian w tradycyjnej kulturze ludów niskorosłych zwracał też uwagę wspominany już C. M. Turnbull. Opisywał korelacje między różnymi formami organizacji społecznej a środowiskiem oraz zmiany zachodzące w kulturze Bambuti z lasu Huri (Demokratyczna Republika Konga $)^{42}$.

${ }^{36} \mathrm{~W}$ tradycji Pigmeje nie nosili nazwisk, w rozmowach między sobą używają tylko imion, współcześnie posługują się także nazwiskami. Być może funkcję nazwiska pełni imię jej ojca, imię „pod jakim znają ich Murzyni” (C. M. Turnbull, Leśni ... op. cit., s. 32) lub jakieś inne określenie nadane urzędowo. W niniejszym artykule - biorąc pod uwagę potrzebę anonimowości - używam tylko imion.

${ }^{37}$ C. M. Turnbull, Leśni ... op. cit., s. 151.

${ }^{38}$ Ibidem. s. 43.

${ }^{39}$ Rozmowa z rodziną pani Nory toczyła się za pośrednictwem przewodnika, który tłumaczył z języka chiga na angielski. Batwa zamieszkujący Bwindi używają języka swych sąsiadów Bachiga, którzy rozpoznają ich tylko po akcencie. Bachiga twierdzą, że „mówią tak jak my, mają tylko inny akcent".

${ }^{40}$ J. Czekanowski, W gląb ... op. cit., s. 272.

${ }^{41}$ https://pl.wikipedia.org/wiki/Paul_Schebesta, dostęp 29.07.2016.

42 C. M. Turnbull, The Mbuti Pygmies: Adaptation and Change, New York: Holt, Rinehart \& Winston 1983. 


\section{Kontakty z rolnikami}

Jan Czekanowski odwiedził wioskę zamieszkaną przez Batwa, znajdującą się o trzy godziny marszu na południe od Nyundo. W owym czasie niektóre wioski były zarządzane przez „,wójtów królewskich”, którzy jednak nie cieszyli się autorytetem wśród Batwa ${ }^{43}$.

W głębi lasu znajdowała się wioska zamieszkała przez Batwa. Żyli z myślistwa i nie uprawiali roli. (...) Jeszcze niedawno lasy sięgały tu znacznie dalej. Toteż i wioska była wtulona głębiej w głuszę leśną. Wtedy Batwa byli jedynymi szczęśliwymi mieszkańcami puszczy. Obecnie rolnicy przysuwali się coraz bliżej. Uderzenia ich siekier powodowały w sercach Batwa niepokój. Byli nieliczni. Nie mogli się skutecznie przeciwstawić ofensywie pokojowej motyki. Żalili się więc tylko na krzywdy; nie mogli wybaczyć rolnikom, że wypłaszali im zwierzynę. Dawno zaniechali prób zbrojnego oporu. Sam król Ruandy, przekupiony przez rolników ... nie bronił już interesów oddanych mu myśliwców. (...) ruchliwy, ongi zwarty szczep, po wyparciu z lasów stanowi obecnie rozprzęgnięte wewnętrznie zbiorowisko pariasów. (...) leśni Batwa nie uprawiali własnych pól, jednakże niekiedy, zmuszeni głodem, pracowali okresowo na polach chłopskich. Najmowali się do pielenia. Ta praca, pokrewna zbieractwu, była dla nich najznośniejsza $(\ldots)^{44}$.

Powyższy cytat, mimo iż pochodzi z początku XX wieku, ma nadal aktualny wydźwięk. Batwa ustępują miejsca rolnikom, są zmuszani do opuszczania lasu i do uprawy roli. Dzisiaj w głębi lasu nie ma już ich osad, a zagrody znajdują się wśród plantacji położonych poniżej granicy lasu. Nie mogą polować, nie żyją więc z myślistwa, co dawniej stanowiło podstawę ich utrzymania. Tym razem z lasu nie wygonili ich rolnicy lecz przepisy mające na celu ochronę dzikich zwierząt. Nadal uważają, że byli szczęśliwi w puszczy i mają żal, że próbuje się z nich zrobić rolników. Nie mają jednak siły, aby z tym walczyć, są zrezygnowani, pogodzeni ze swym losem. Nie znaczy to jednak, że stali się dobrymi rolnikami ${ }^{45}$.

Jeszcze w latach 30. XX w. Batwa prowadzili zbieracko-łowiecki tryb życia. Polski podróżnik Kazimierz Nowak, który w latach 1931-36 przebył samotnie

${ }^{43}$ J. Czekanowski, W głą ..., op. cit., s. 36.

${ }^{44}$ Ibidem, s. $40-41$.

${ }^{45} \mathrm{Z}$ problemem zmiany podstaw gospodarczych zetknęło się wiele ludów, profesor Alfred F. Majewicz podobną zmianę opisuje na przykładzie Ajnów - ludności autochtonicznej zamieszkującej Hokkaido. Wskutek wpływów japońskich zostali oni zmuszeni do uprawy roli. „Wymuszone rolnictwo (Ajnów - LB) ani nie było efektywne, ani nie rekompensowało strat spowodowanych zakazami polowań i łowów, nadto przyczyniło się do dezintegracji tradycyjnych grup i układów społecznych zależnych od terenów łowieckich, rybackich czy zbierackich. Ponieważ zarówno te grupy i układy, jak i gospodarka, na której się one opierały, miały bardzo ścisły związek z religijnymi wierzeniami i światopoglądem Ajnów, także i ten fundament duchowej tożsamości tego ludu począł się walić” (A. F. Majewicz, Dzieje i wierzenia Ajnów, Poznań: CIA-Books-SVARO, Ltd. 1991, s. 33). Podobny efekt już widać u Batwa i zapewne będzie się on jeszcze pogłębiał. 


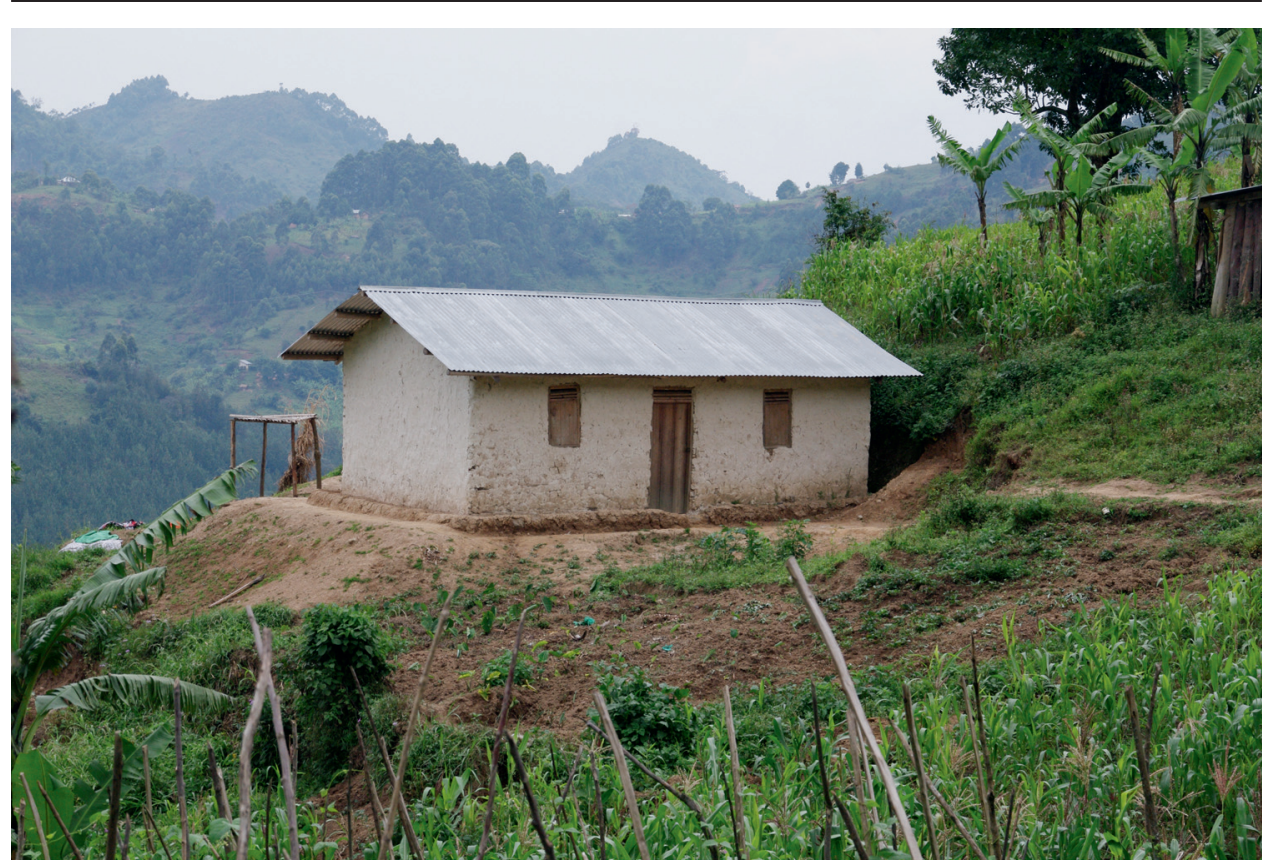

Zagroda Batwa we wsi Bwindi, fot. L. Buchalik.

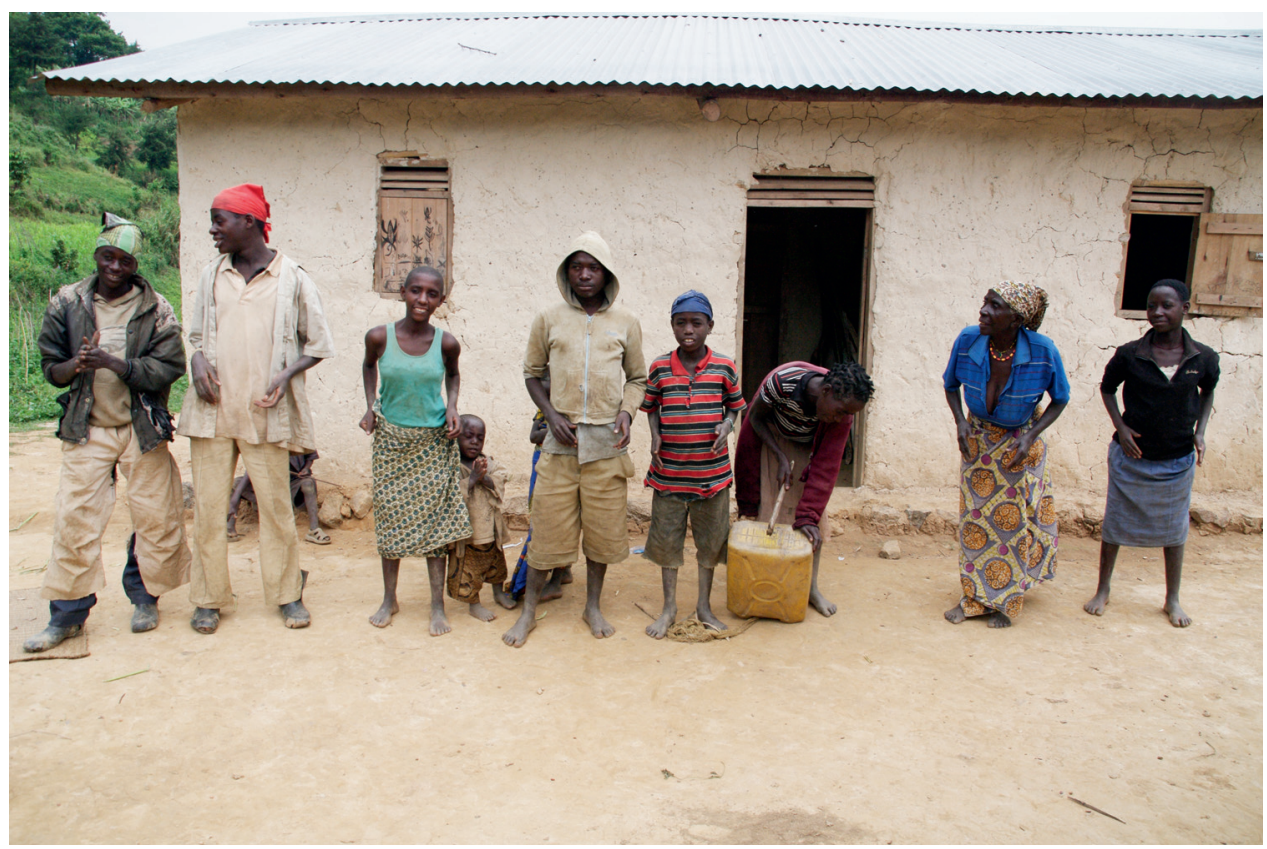

Rodzina Nory z Bwindi prezentuje folklor Batwa, fot. L. Buchalik. 
kontynent afrykański pisze, że, według niego, Batwa, co prawda należą do Pigmejów, ale są zmieszani z „rasą Bahutu, następstwem czego wzrost ich jest raczej średni. (...) Żyją jak wszystkie karły w lesie dziewiczym, a trudnią się wyłącznie polowaniem" ${ }^{46}$. Czekanowski ukazał różnicę między Batwa, dla których puszcza była domem, schronieniem, miejscem przyjaznym a rolnikami, dla których była obca. W połowie XX w. C. M. Turnbull zanotował słowa Pigmejów: „Dlaczego mieliśmy obawiać się lasu? Jesteśmy przecież jego dziećmi, boimy się tylko tego, co jest poza puszczą"47. Inna zaś była opinia rolników „,puszcza była zdaniem Murzynów czymś złym: pełna zwierząt, złośliwych duchów i Pigmejów"48. Ta opozycja pozostała aż do czasów wypędzenia Batwa z puszczy Bwindi, teraz mieszkają wśród rolników i próbują funkcjonować w nowym, obcym dla siebie świecie. Zdaniem Pigmejów różnica między nimi a rolnikami z wiosek widoczna jest przede wszystkim w zachowaniu w puszczy, ci pierwsi są dziećmi lasu a ci drudzy „nie umieją chodzić po lesie"49.

Kilkadziesiąt lat wcześniej, opisując domostwo Batwa Jan Czekanowski zauważa, że:

(...) nie posiadali w ogóle żadnych sprzętów. Nie mieli pomostów zastępujących łoża. Spali bezpośrednio na ziemi i pod tym względem różnili się zasadniczo od reszty mieszkańców Ruandy. Nieliczne garnki i drewniane misy-talerze to było wszystko, co posiadali w tym zakresie. Natomiast prawie w każdej chacie spotykało się instrumenty muzyczne. Byli przecież nadwornymi muzykantami i śpiewakami. Widziałem w chatach tych leśnych Batwa cytry (inanga), flety i grzechotki $(\ldots)^{50}$.

Instrumenty muzyczne opisywane przez Czekanowskiego można i dzisiaj spotkać na targach, a szczególne popularne są grzechotki, flety oraz cytry znane na terenie całej Ugandy. Obecnie tradycyjne bębny, wykonane z drewna i skóry, są zastępowane przez popularne w Afryce plastikowe kanistry na wodę (zjawisko to obserwowałem także w Afryce Zachodniej), uderza się w nie pałeczkami podobnymi do tych, którymi gra się na bębnach.

C. M. Turnbull twierdził, w przeciwieństwie do P. Schebesty, że Pigmeje nie byli zależni kulturowo od rolników Bantu. Ilustrował to przykładem inicjacji nkumbi zapożyczonej od rolników, którą naukowcy interpretowali jako zależność Pigmejów od ludów sąsiednich. M. C. Turnbull uważał jednak, że nie mają oni racji. Pigmeje uczestnicząc w rytuale inicjacji „nie czuli się skrępowani zwyczajem

${ }^{46}$ K. Nowak, Rowerem i pieszo przez Czarny Lą. Listy z podróży afrykańskiej z lat 1931-1936, Poznań: SORUS S.C. Wydawnictwo i Drukarnia 2008, s. 145.

${ }^{47}$ C. M. Turnbull, Leśni ..., op. cit., s. 70.

48 Ibidem, s. 51.

49 Ibidem, s. 75.

50 J. Czekanowski, W głąb ... op. cit. s. 42. 
cudzym, bo murzyńskim, i zaprosili mnie, bym w nim pozostał" ${ }^{51}$. Gdyby to był ich zwyczaj, to obawialiby się, że moce nadnaturalne ukarałyby ich za przekroczenie zakazu, tzn. udziału w nim obcego, a że nie był to jednak ich zwyczaj, to nie martwili się konsekwencjami. Nie zmienia to jednak faktu, że Pigmeje często przyjmowali zwyczaje sąsiadów. Innym przykładem takich zapożyczeń były obrzędy pogrzebowe ${ }^{52}$.

W połowie XX w. obóz zamieszkiwany przez Pigmejów nad Iturii „był założony na wzór wsi murzyńskiej: lepianki stały w dwóch szeregach naprzeciw siebie. Lepianki miały długość tylko siedmiu, a szerokość pięciu stóp, jedne nie miały dachu, inne nie miały ścian i właściwie żadna nie była ukończona" ${ }^{53}$. Na początku XXI w. domostwa Batwa są usytuowane wewnątrz wioski, wśród zabudowań rolników. Na zewnątrz ich obejścia niewiele różnią się od innych. Zagroda pani Nory składa się z dwóch budynków: mieszkalnego i gospodarczego oraz niewielkiego podwyższenia na produkty spożywcze i naczynia kuchenne. Ściany budynków mają lekką konstrukcję drewnianą wypełnioną gliną, ściany są wygładzone i pomalowane na biało. Budynek mieszkalny ma dwuspadowy blaszany dach, dwoje drzwi i cztery okna wykonane z drewna. Składa się z przedsionka i czterech pomieszczeń: sypialni seniorki, dwóch sypialń dla dzieci i „pokoju gościnnego”. W odczuciu człowieka Zachodu wyposażenie jest bardzo skromne, a we wnętrzu panuje nieład. W sypialni seniorki jest niewielkie podwyższenie pełniące funkcje łóżka. Dzisiaj „tradycyjne łóżko” Pigmejów to konstrukcja wykonana z gałęzi powiązanych pnączami, czasami pokrytych liśćmi. Na łóżku leży mata i koce do przykrycia, nad nimi wisi moskitiera. W pozostałych pomieszczeniach znajduje się kilka mat i kocy, ubiory są rozrzucone w nieładzie, choć niektóre są powiązane w tobołki. Według C. M. Turnbulla, w połowie XX w. Batwa zaczęli używać mat, które podkradali swoim sąsiadom Bantu. Wcześniej nie korzystali z łóżek, a jedynie układali gałęzie na ziemi i na nich spali lub układali się do snu bezpośrednio na suchych liściach przyniesionych do szałasu ${ }^{54}$.

Pomieszczenie gospodarcze jest zdecydowanie mniejsze, ma drewniane drzwi i okno. Pełni ono funkcję kuchni i małego magazynu. W kuchni znajduje się tradycyjne palenisko składające się z trzech kamieni a na nim metalowe naczynia służące do gotowania, gliniane garnki kupione od Bachiga, drewniany stołeczek, taca do przesiewania i czyszczenia ziarna.

W zagrodzie znajdowała się pozbawiona drewnianej rękojeści maczeta omuho$r u$ (jęz. chiga), służąca do usuwania chwastów z pola ${ }^{55}$. Narzędzia są dla rolników

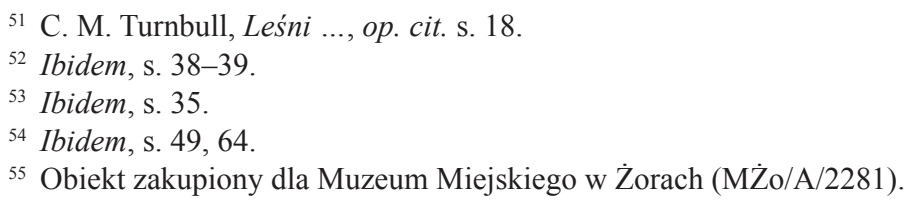


ważnymi przedmiotami, dbają o nie i w należyty sposób przechowują. Można było zatem odnieść wrażenie, że w zagrodzie pani Nory, to narzędzie było obce. Widać tu brak szacunku do narzędzi rolniczych oraz niechęć do uprawy roli. Wielkim sentymentem natomiast Batwa nadal darzą łuk. W odwiedzanej zagrodzie, łuk, którym bawiło się dziecko, był jednym z nielicznych elementów/rekwizytów dawnego życia.

\section{Działalność państwa}

$\mathrm{Na}$ terenach opisywanych przez profesora Czekanowskiego, kontakty Batwa - czy też generalnie ludów zbieracko-łowieckich - z okolicznymi rolnikami sięgają zamierzchłej przeszłości. Dzisiaj trudno określić, kiedy się rozpoczęły i jak następował proces przemiany tradycyjnej kultury Batwa. Kontakty nawiązywano zapewne w sposób naturalny i w ewolucyjny sposób zmieniały one codzienne życie tego ludu. Współcześnie proces przemian gwałtownie przyspieszył. Związane jest to z działalnością tak gospodarczą jak i polityczną państw zamieszkiwanych przez tę grupę.

Przewodnik Ben mówi, że „kiedy utworzono Park Narodowy Bwindi, Batwa musieli wyjść z lasu, nie mieli co ze sobą zrobić". To jedno proste stwierdzenie, oddaje dramat tej społeczności. Aby pomóc Batwa odnaleźć się w nowej sytuacji powstało Stowarzyszenie Nkuringo Cultural Center. Jego celem jest wspieranie Pigmejów, chronienie ich dziedzictwa a także pomoc w rozwiązywaniu aktualnych problemów życiowych. „Stowarzyszenie wykupiło ziemię i osiedlili na niej Batwa, którzy powoli stają się rolnikami. Nie polują już ani nie zbierają owoców w Parku. Chcemy ułatwić życie Batwa, i przystosować ich do nowej rzeczywistości" ${ }^{56}$. Projekt ten ma sens, bowiem Batwa, mimo iż byli koczownikami gospodarującymi w lesie, często wynajmowali się do prac rolnych. Praca w rolnictwie nie więc jest dla nich wielkim szokiem kulturowym.

Wymieniony wyżej przykład można zaliczyć do udanych projektów. Są jednak także projekty chybione, jak na przykład „Pottery Projekt” obserwowany przez Jacka Łapotta w 2007 r. Realizowany jest on w Kigali (Rwanda), gdzie w atelier „Dancing Pots" uczy się mężczyzn robienia garnków na elektrycznym kole garncarskim. Ich wyroby są nowoczesne, nie nawiązują do tradycji, można je nabyć w pobliskim sklepie. Problemem jest fakt, że urządzenie może być używane tylko w mieście gdzie jest prąd. Przede wszystkim jednak, podstawową kwestią jest fakt, że w projekcie tym uczestniczą mężczyźni. W myśl tradycji w tym rejonie produkcja garnków była domeną kobiet. Trudno sobie wyobrazić, żeby mężczyźni z własnej woli zajęli miejsce kobiet na rynku garncarskim. Wspomniany projekt jest przykładem nieliczenia się z tradycją.

56 Informator Ben. 
Wizyta w zagrodzie Batwa budzi mieszane uczucia. W opinii moich rozmówców musieli oni opuścić las ze względu na ochronę zwierzą ${ }^{57}$. Zmieniono ich życie, „przerobiono na rolników”, z czym trudno im się pogodzić. W tym miejscu można zadać pytanie: co, czy kto tu jest ważniejszy, zwierzęta czy ludzie. To poważny - współcześnie - chyba nierozwiązywalny problem. Kwestię tę w latach 60. XX w. podnosił Roman Turski, który przebywał w Gabonie wśród Babingów. Pigmeje Babinga byli wypierani przez rolników w coraz bardziej niedostępne wilgotne puszcze, a ich źródłem utrzymania pozostawało zbieractwo i łowiectwo. Jednocześnie władze państwowe zabroniły im posiadania broni palnej. W konsekwencji Babinga pozostawali w silnej zależności od rolników, którzy traktowali ich jak niewolników ${ }^{58}$.

J. Czekanowski nie wspomina nawet o próbach edukacji Pigmejów. Obecnie misjonarze próbują kształcić ich dzieci, lecz efekty tego działania są nikłe. Ksiądz Wojciech Lula opisuje problemy skolaryzacji pigmejskich dzieci w Republice Środkowoafrykańskiej. Nie były one poddawane edukacji, bo cieszyły się niedobrą opinią, „nie dawano im żadnych szans, by pokazać ich inteligencję. Dyskryminowano ich w edukacji z uwagi na tradycyjny, półkoczowniczy tryb życia w lesie. Skoro w lesie to tak jak zwierzęta. Jeżeli zwierzęta, to czy mogą się one czegokolwiek nauczyć? Niektórzy nawet, w ich rozumowaniu, poddawali w wątpliwość istnienie u nich jakiejkolwiek inteligencji!!!"59. Autor wspomina również o innym, ważnym z kulturowego punktu widzenia problemie, pojawiającym się przy nauczaniu dzieci pigmejskich.

W szkole w miejscowości Barka miejsce wyrozumiałej siostry zajęła inna osoba, na dodatek z plemienia, które w historii przeważnie wykorzystywało Pigmejów, nasi młodzi podopieczni zaczęli nabierać niechęci do pobytu w szkole. (...) Dzieci nie czuły się w niej już dobrze. (...) Inne dzieci po prostu, najpierw uciekły rodzicom z domu, poszły z rówieśnikami do lasu na cztery czy pięć miesięcy, potem zapisały się jeszcze do naszej podstawówki we wiosce, gdzie poziom był niższy i gdzie nie trzeba tak ciężko pracować. Tak, więc z 12 dzieci na koniec zeszłego roku, ... pozostało nam już tylko sześcioro $^{60}$.

Batwa z Bwindi nie są jedynym przykładem wysiedlania autochtonów z ich ziem. Wspomniany już C. M. Turnbull w książce Ikowie ludzie gór ${ }^{61}$, która jest relacją z kilkuletniego pobytu autora wśród mieszkańców trudno dostępnych gór na pograniczu Ugandy, Sudanu Południowego i Kenii, opisuje inny przypadek wysie-

${ }^{57}$ Informatorzy: Nora, John.

${ }^{58}$ R. Turski, Żyłem wśród Pigmejów, „Poznaj Świat” nr 4, 1970, ss. 34-35.

${ }_{59}$ W. Lula, Nowa droga w edukacji pigmejskich dzieci, „Wrota Afryki”, nr 60, czerwiec-sierpień 2016, s. 6.

${ }^{60}$ Ibidem.

${ }^{61}$ C. M. Turnbull, Ikowie ludzie gór, Warszawa: Państwowy Instytut Wydawniczy 1980. 
dleń. Po utworzeniu rezerwatu w dolinie Kidepo - podobnie jak Batwa z Bwindi - Ikowie zostali pozbawieni swych naturalnych terenów łowieckich, czyli podstawowego źródła egzystencji ${ }^{62}$. Rząd zabronił dwom tysiącom osób polować w parku i nakazał im uprawiać ziemię. Kiedy pola na zboczach stają się jałowe, przenoszą się oni na stoki doliny, ale są to tereny przeznaczone dla zwierząt ${ }^{63}$. Aby zrozumieć problem Pigmejów wypędzonych z puszczy należy zadać pytanie, czym jest dla nich las. W książce tegoż autora poświęconej Pigmejom znad Iturii znajduje się kilka ciekawych sugestii na ten temat. Już samo motto jest interesujące ,... puszcza jest matką i ojcem, kochanką i przyjacielem ...”. Informatorzy Turnbulla mówią: „Puszcza jest nam ojcem i matką (...) i jak ojciec i matka daje nam wszystko, czego potrzebujemy: żywność, odzienie, schronienie, ciepło ... i miłość" ${ }^{4}$. Ilustracją tych tęsknot są pieśni śpiewane przez zespół folklorystyczny w Nyabaremura.

Władze sąsiedniej ,Tanzanii chcą dokonać eksmisji ponad 60 tysięcy Masajów z ich rdzennych terenów. Politycy twierdzą, że ma tam powstać „korytarz ochronny", czyli rezerwat dzikiej przyrody. Jednak - jak twierdzą działacze sprzeciwiający się wysiedleniom - tak naprawdę chodzi o przygotowanie terenu, na którym urządzane będzie luksusowe safari dla bogatych turystów z Emiratów Arabskich"65.

Taka sama sytuacja panuje w Botswanie, gdzie niskorosłe ludy San wysiedlane są z rezerwatów przyrody ${ }^{66}$.

W 2010 r. Botswańczyk Kuela Kiema opisał w książce wysiedlenie swojego ludu - liczącego ok. 2 tys. osób Kua: Walczyliśmy z rządem od długiego czasu. Zmuszali nas do wyprowadzki, ale opieraliśmy się. Rząd wprowadził prawa, które zabraniały nam polowań, co także znaczyło, że nie mogliśmy nawet zabijać drapieżników zagrażających nam i naszym zwierzętom. Gdybyśmy zabili lwy albo dowolne zwierzę, które zabijało

${ }^{62}$ U ludów zbieracko-łowieckich umiejętność samodzielnego polowania jest oznaką osiągnięcia dorosłości. U Babingów „,chłopiec, który przeszedł próby inicjacji i samodzielnie upolował zwierzynę, dał tym samym dowód, że potrafi utrzymać rodzinę. Uważa się go za dorosłego, może więc starać się o żonę" (R. Turski, Żyłem ... op. cit., s. 35). Tak było w połowie XX w., kiedy tworzono parki narodowe, wraz z ich powstaniem i nałożeniem zakazów na myśliwych pojawił się poważny problem: w jaki sposób młody człowiek ma udowodnić, że jest dorosły, zdolny do samodzielnej egzystencji, skoro polowania są zakazane. Dla lokalnych wspólnot zbieracko-łowieckich zamieszkujących tereny chronione bądź ich okolice (parki narodowe, rezerwaty), pojawia się problem, jak zmienić życie, tradycje tak, aby uznać młodego człowieka za gotowego do zawarcia związku małżeńskiego. W tej sytuacji pojawia się pytanie: czy miłośnicy ochrony przyrody wzięli pod uwagę los tych małych wspólnot?

${ }^{63}$ C. M. Turnbull, Ikowie ... op. cit.

${ }^{64}$ C. M. Turnbull, Leśni ... op. cit., s. 89.

65 http://wiadomosci.gazeta.pl/wiadomosci/1,114871,13840706,Rzad_wyrzuca_60_tys_Masajow_z_ich_ziemi_Chce_tam.html (dostęp 02.05.2013).

${ }^{66}$ Wysiedlano także z terenów nie będących rezerwatami, gdzie zamierzano budować kopalnie. 
nasze zwierzęta hodowlane, zostalibyśmy wtrąceni do więzienia. W końcu poddaliśmy się, żeby uchronić małe kozy, konie i osły, które jeszcze zostały, i przeprowadziliśmy się tam, gdzie chciał rząd ${ }^{67}$.

Słabe ludy przygrywają z ideą ochrony przyrody. W Bwindi Batwa przegrali z gorylami, pozostało im tylko o nich śpiewać. Jedną z takich pieśni (i tańców) zaprezentowano w zagrodzie Nory. W pieśni tej Batwa z wielkim szacunkiem odnoszą się do goryli, traktując je nie jako zwierzynę łowną, lecz ,panów lasu”. Różnica między ludźmi i tymi zwierzętami polega na tym, że goryle pozostały w lesie a Batwa musieli go opuścić. Kiedy jeszcze przebywali w puszczy, często śpiewali pieśni molimo, o których wielokrotnie wspomina C. M. Turnbull ${ }^{68}$. Są one często pochwałą puszczy i stanowią swego rodzaju pieśni dziękczynne. Taki wydźwięk miały również pieśni śpiewane $\mathrm{w}$ roku w zagrodzie u pani Nory.

W Demokratycznej Republice Konga, w latach 50. XX w., Pigmeje z lasów nad Ituri byli zachęcani przez administrację do tworzenia własnych plantacji bananów. Już wtedy zwracano uwagę, że „kiedy Pigmeje będą mieli plantacje, będą musieli zarzucić dotychczasowy sposób życia jako myśliwi i zbierający płody puszczy. Będą związani z jednym miejscem i nie będą mieli czasu tropić zwierzyny ${ }^{69}$. Wśród samych Pigmejów zdania były podzielone. Jeden ze starszych mieszkańców - o imieniu Tungana - był zwolennikiem tworzenia plantacji, twierdził, ,że wygodnie jest mieszkać blisko wsi, gdyż tam łatwo jest podkradać sporo dobrego jadła, a kraść jest przecież łatwiej niż polować"70. Inni Pigmeje mówiąc o możliwości prowadzenia osiadłego trybu życia, zwracali uwagę, że wkrótce wrócą do lasu, bo tam jest ich gniazdo. „Nie możemy wyrzec się lasu”

\section{Wpływ turystyki}

Współcześnie często podnosi się kwestię niszczenia tradycyjnych kultur przez masową turystykę. Nie jest to nowe twierdzenie, ,kiedy w latach dwudziestych pierwsi amerykańscy antropolodzy wracali z Bali, opisywali z zatroskaniem, jak kultura balijska zostanie kompletnie zniszczona przez turystykę (w latach dziewięćdziesiątych nadal do tego nie doszło ${ }^{72}$ - wiele podobnych ponurych przepowiedni wygłaszano w imieniu ludów, które badała antropologia"73.

\footnotetext{
${ }^{67}$ A. Leszczyński, Spieszmy się stuchać mlasków, „Gazeta Wyborcza” 25.07.2014.

${ }^{68}$ C. M. Turnbull, Leśni ... op. cit.

${ }^{69}$ Ibidem., s. 28.

${ }^{70}$ Ibidem., s. 29.

71 Ibidem., s. 34.

72 U. Wikan, Managing Turbulent Hearts, Chicago: University of Chicago 1992; F. Barth, Balinese Worlds, Chicago: University of Chicago Press 1993.

73 T. H. Eriksen, Małe miejsca, wielkie sprawy. Wprowadzenie do antropologii społecznej $i$ kulturowej, tłum. Joanna Wołyńska, Warszawa: Oficyna Wydawnicza Wolumen 2009, s. 306.
} 
Na początku XX w., kiedy w Ugandzie przebywał profesor Czekanowski „Ruwenzorii, a zwłaszcza kraj Baamba na jego stokach zachodnich i na podgórzu aż po rzekę Semliki na zachodzie, były terenami zamkniętymi dla podróżnych ze względu na niezadawalające warunki bezpieczeństwa, innymi słowy, były dostępne jedynie dla przemytników, którzy się tam włóczyli na własne ryzyko"74. W innym miejscu badacz wspomina, że w kraju Baamba ,nie było żadnych innych dróg prócz ścieżek wiodących od wioski do wioski"75. Na początku XXI w. wybudowano tu jednak wygodną drogę asfaltową, którą bez przeszkód można objechać Masyw Ruwenzorii i zwiedzać Semuliki National Park. Leży on na północ od Fort Portal przy granicy z Demokratyczną Republiką Konga, po trzydziestu minutach jazdy wygodnym asfaltem można dojechać do Itajo, gdzie jest zjazd do Semuliki Wildlife Reserve.

Obecnie, jak informuje folder Semuliki National Park:

W otoczeniu parku mieszkają cztery grupy etniczne. W dolinach oraz na stokach górskich możemy spotkać Baamba i Bakondjo. Są oni rolnikami, którzy uprawiają rośliny przynoszące zyski takie, jak kawa i kakao, a sami spożywają zboża, banany ryż i ziemniaki. Na północ od parku, doliny i równiny są zajmowane przez pasterzy Batuku. Mała grupa w dolinie to społeczeństwo Batwa (Pigmeje). Tradycyjnie byli oni mieszkańcami lasu, łowcami i zbieraczami pochodzącymi z Ituri. Ich styl życia obecnie uległ zmianie z powodu kontaktów z innym lokalnymi społecznościami oraz pod wpływem turystyki. (...) Obecnie na małą skalę utrzymują się z uprawy i wpływów z wizyt turystów ${ }^{76}$.

W czasie mojego przejazdu na trasie Fort Portal - Ntoroko nie udało mi się spotkać Pigmejów. Kierowcy zwracali uwagę na miejscowe bogactwo dzikich zwierząt, lecz na temat Pigmejów nie potrafili się wypowiedzieć. Są to jednak tereny przez nich zamieszkane, bowiem wspominał o tym profesor Czekanowski ${ }^{77}$, a Jacek Łapott w 2007 r. spotkał Pigmejów na trasie do Ntoroko. Zaobserwował ich grupę przebywającą $\mathrm{w}$ pobliżu drogi i zachęcającą turystów do wizyty w wiosce (za niewielką opłatą,10 $000 \mathrm{USh}^{78}$ ). Pigmeje oferowali sprzedaż fajek, fletów i przyrządów do rozniecania ognia ${ }^{79}$, w zamian chcieli otrzymać mydło, T-shirty i czapki.

Pigmeje znad Ituri zetknęli się z turystami w połowie XX w. co relacjonował wspominany Turnbull:

${ }^{74}$ J. Czekanowski, W głą ... op. cit., s. 169.

75 Ibidem., s. 197.

${ }^{76}$ B.a., Semuliki National Park. The True Birders' Haven, Kampala, b.d.

77 J. Czekanowski, W głab ... op. cit., s. 256.

${ }^{78}$ Szylingi ugandyjskie.

79 Zakupiony przez Muzeum Miejskie w Żorach od turysty z Wrocławia, który nabył go od Pigmejów w zachodniej Ugandzie (sygn. MŻo/A/2488). 
Obóz [Pigmejów - LB] znajdował się w pozycji strategicznej między wsią pracowników motelu a stacją polowań i obozem Putnama ${ }^{80}$, w pobliżu sklepów i piwiarni, a co najważniejsze - w pobliżu otaczających plantacji. Stary Tungana orzekł, że było to dobre miejsce, gdyż turyści będą przejeżdżać tuż obok, będą robić zdjęcia i dawać pieniądze Pigmejom. (...) Pigmeje upodobnili się do takich zawodowców, jacy mieszkali na skraju lasu przy drodze do Beni ${ }^{81}$. Tamci oferowali swe usługi turystom pozwalając, by ich fotografowano, wykonując czynności, których nigdy by nie wykonywali w puszczy, nosząc odzienie, którego nigdy by nie przyoblekali, jak tylko we wsi, teraz zaś sprzedawali turystom nawet broń używaną tylko przez Murzynów ${ }^{82}$.

W owym czasie Pigmeje znad Ituri nie byli szczególną atrakcją dla turystów, większym zainteresowaniem cieszyła się Station de Chasse. „Placówka ta ze swoją kolekcją żywych zwierząt puszczy przyciągała zamożnych turystów, mających dość czasu i pieniędzy, by wybrać się tu na wycieczkę ze Stanleyville czy z Beni"83.

Na początku XXI w. sytuacja wygląda podobnie. Na pozór jeden z nielicznych ludów niskorosłych Afryki powinien być ,atrakcją” turystyczną. Jest to jednak mylne założenie. Do Ugandy przyjeżdża się głównie ze względu na obecne tu dzikie zwierzęta i wydaje się, że główną atrakcją są goryle. Jest wiele reklam trekkingu „do goryli” oraz wiele pamiątek związanych z tymi zwierzętami (rzeźby goryla, samicy z małymi, koszulki z gorylami, itp.). Pamiątek nawiązujących do kultury Pigmejów nie ma. Przy miejscowym hostelu działa Biuro Turystyczne Engagi ${ }^{84}$ Safaris Ltd. Jego dyrektor Robert zachęca do skorzystania z oferty, czyli kilkudniowej wycieczki w góry, której celem jest stanięcie „oko w oko” z gorylem. Potrafi on też zorganizować wyjazd do Pigmejów jak powszechnie nazywa się tu Batwa, ale jest to jednak oferta rzadko wybierana przez turystów, dlatego szczegóły takiej tury musi on długo uzgadniać w podwykonawcami w terenie.

Podobną sytuację - odwiedzanie wiosek przy okazji wizyty w parku narodowym - zaobserwowałem w północnym Beninie. Turyści przyjeżdżający do Natitingou, wynajmują samochody i jadą oglądać dzikie zwierzęta w Parku Naro-

${ }^{80}$ Patrick Putnam (1904-53), amerykański antropolog, pracujący w Kongo z ramienia Harvard University. „W obozie swego imienia założył aptekę i kolonię dla trędowatych. Ze swego domu mieszkalnego zrobił hotel, a dochody obrócił na cele lecznictwa" (C. M. Turnbull, Leśni ... op. cit., s. 17).

${ }^{81}$ Miejscowość tę odwiedził również J. Czekanowski, był tam w dniach 8-10 luty 1908 r. (J. Czekanowski, W głąb ... op. cit., s. 261-266).

${ }^{82}$ C. M. Turnbull, Leśni ... op. cit., s. 33-34. Podobne zjawisko można obserwować u ludów w południowo-zachodniej Etiopii (głównie Mursi), gdzie ruch turystyczny, a szczególnie proceder płacenia za zdjęcia, spowodował, że odwiedzani mieszańcy wiosek, chcąc być fotografowani przez turystów, a co za tym idzie otrzymać pieniądze, wymyślali nowe wzory malowane na swoich ciałach. Zachowanie odwiedzanej społeczności doskonale pokazuje holenderski film dokumentalny z 2012 r. pt. Framing the other (polski tytuł $Z$ kamera wśród ludzi) w reżyserii Ilja Koka i Willema Timmersa.

${ }^{83}$ C. M. Turnbull, Leśni ... op. cit., s. 164.

${ }^{84}$ Termin engagi oznacza w jęz. chiga goryla. 
dowym Pendjari, który jest główną atrakcją tego terenu. Wioski znajdujące się w promieniu kilkunastu kilometrów od Natitingou na trasie wiodącej do Parku, oddalonego o kilkadziesiąt kilometrów (prawie dwie godziny jazdy) są odwiedzane niejako przy okazji wyprawy.

Chcąc spotkać się z Batwa należy wjechać w góry, a droga kończy się we wsi Rubuguri (dystrykt Kisoro, Zachodnia Uganda), położonej na wysokości około 1900 m n.p.m., na obrzeżach National Park Bwindi. Osada jest często odwiedzana przez turystów, dlatego przy drodze znajduje się wiele tablic informacyjnych. Z biura turystycznego, wyruszając z przewodnikiem, można podjechać do Nyabaremura, skąd trzeba iść dalej pieszo. Znajduje się tutaj lokalne Centrum Kultury utworzone przez wspomniane już stowarzyszenie Nkuringo Cultural Center.

Turystów w Centrum wita przewodnik Issa, on też oprowadza po wystawie muzealnej. Przedstawia ona kulturę ludów zamieszkujących ten teren, jednak o Batwa niewiele jest mowy. Po wizycie w muzeum, odwiedzający oglądają występ zespołu prezentującego folklor Batwa. Według przewodnika członkami grupy są ludzie Batwa należący do Stowarzyszenia. W rzeczywistości są to różne osoby (także Bachiga), zamieszkujące pobliskie tereny. Instrumenty muzyczne na czas koncertów pożyczają z wystawy, którą zwiedzają turyści i po koncercie są odkładane na swoje miejsce. Zespół wykonuje pieśni i tańce o dawnym życiu w lesie. Jedna z pieśni - śpiewana w języku chiga - mówi, że Batwa już nie mogą chodzić do lasu, zbierać owoców, polować, muszą pracować na polach i plantacjach, tęsknią za dawnym życiem. Batwa wspominają szczęśliwy czas, kiedy mogli polować w puszczy, teraz muszą ciężko pracować w polu.

Do położonej w górach wioski Bwindi (kilka kilometrów od Rubuguri), można dotrzeć tylko piechotą w towarzystwie uzbrojonego strażnika i przewodnika. Zabudowa jest rozproszona, domy położone są wśród pól. Dojście do wioski, położonej tuż za granicą National Park Bwindi ${ }^{85}$, prowadzi wąską ścieżką. Przewodnik Ben twierdzi, że „we wsi mieszka ok. 30-40 Pigmejów Batwa. Mieszkańcy zagrody są czasami odwiedzani przez turystów, którzy idą do Parku zobaczyć goryle". Za niewielką opłatą oferują popisy muzyczno-taneczne, w wykonaniu licznej rodziny oraz sąsiadów.

Według przewodnika Bena, tygodniowo do biura obsługującego turystów w Rubuguri przyjeżdża około 100 osób, którychi celem jest ,wizyta w lesie i oglą-

${ }^{85}$ Nieprzenikniony Las Bwindi (Bwindi Impenetrable Forest), obszar wilgotnych lasów równikowych w południowo-zachodniej Ugandzie, w górach na obrzeżach Wielkich Rowów Afrykańskich, rozpościerający się na powierzchni 331 km², na wysokości 1160 do 2607 m n.p.m. Większa część obszaru lasu od 1991 r. objęta jest ochroną w ramach Parku Narodowego Bwindi (Bwindi Impenetrable National Park), w 1994 r. wpisany na listę światowego dziedzictwa UNESCO (http:// pl.wikipedia.org/wiki/Nieprzenikniony_Las_Bwindi, dostęp 04.08.2014). 
danie goryli, przy okazji przychodzą też do zagród Batwa. Goryle są ciekawsze dla turystów”. Victor z biura Engagi, który pokazywał mi drogę, twierdzi, że „ludzie przyjeżdżają oglądać goryle, bo ich jeszcze nie widzieli, jest to najważniejszy powód przyjazdu turystów. Do Pigmejów idą tylko przy okazji, bo ich oni nie interesują". Nie potrafił wytłumaczyć, dlaczego tak się dzieje. W czasie rozmowy wielokrotnie podkreślał, że „goryle są najważniejsze. To najdroższa rzecz tutaj. Trekking do goryli kosztuje 500 USD". Podobnego zdania jest Cherotwo, przewodnik pracujący w Sipi Falls Tour (okolice Mbale). Akcentuje on przyrodnicze atrakcje turystyczne Ugandy (zwierzęta, krajobrazy). Na pytanie o kulturę Ugandy, jej lokalne tradycje, odpowiadał mało konkretnie używając ogólników typu „No tak to też jest ciekawe”.

Największą różnicą w porównaniu z latami, kiedy w Ugandzie przebywał Jan Czekanowski, a przynajmniej najbardziej rzucającą się w oczy, jest rozwój turystyki. Rozpoczął się on już na początku XX wieku, o czym wspominał sam profesor, kiedy przebywał w Nyanza (Rwanda):

Przybyli tam pierwsi turyści: dr Römer, jakiś potentat finansowy interesujący się zagadnieniami kolonialnymi, zapewne w celach utylitarnych, towarzyszący mu dr Autenrieth, przypuszczalnie jego podwładny. (...) Dr Römer zaskoczył mnie wtedy swoim negatywnym stosunkiem do władz kolonialno-wojskowych, którym zarzucał, że bawią się w murzyńskich feudałów i uniemożliwiają gospodarczą eksploatację tych części kolonii, które pozostają w administracji wojskowej ${ }^{86}$.

Na początku XX w. wizyty takie były jednostkowe, rzadkie a i tak - sądząc z opisu Czekanowskiego - celem pobytu wspomnianych osób nie były li tylko względy turystyczne we współczesnym tego słowa rozumieniu. Łączono wówczas pobyt na tych terenach $\mathrm{z}$ interesami lub innymi działaniami zawodowymi. Współcześnie Uganda jest bardzo popularna wśród turystów. Może świadczyć o tym duża ilość informacji dostępnych w Internecie. Serwis TripAdvisor oferuje 41421 recenzji i artykułów na tematy interesujące osoby pragnące odwiedzić ten kraj. Jest tu dobrze rozwinięty przemysł pamiątkarski, oparty głównie na dawnych rzemiosłach i dający pracę wielu osobom.

W Kampali jest kilka miejsc, gdzie turysta może zaopatrzyć się w pamiątki. Jednym z nich jest targowisko przy Parlamencie National Arts and Craft Association of Uganda, którego nie było za czasów Czekanowskiego. Oferta skierowana jest do turysty, szczególnie rzucają się w oczy współczesne zabawki: drewniane samochodziki, piłki z liści bananowca, żółw z kapsli od butelek piwa Pilsner Lager, samolot z kapsli od butelek piwa Tusker, ludzik z kapsli od butelek piwa Bell. Obiekty te nie posiadają oryginalnych nazw lokalnych, na ich określenie sprzedawczyni używała terminów z j. angielskiego. Nieco inny charakter mają stragany

${ }^{86}$ J. Czekanowski, W głą ... op. cit., s. 37-38. 
przy Natete Road w Kampali w pobliżu Backpackers Hostel. Targowisko, to także miejsce wyrobu przedmiotów tradycyjnych, głównie instrumentów muzycznych. Można tutaj kupić różne ich typy: bębny (duży wybór, różne rozmiary i rodzaje), harfy, zanzy (metalowe i drewniane), kilka rodzajów grzechotek, grzechotki skrzynkowe, spódniczki z rafii, fletnie pana, piszczałki wykonane z drewna i gumy z dętki ${ }^{87}$, a także przedmioty codziennego użytku: gliniane piecyki, stępy i stępory, plecione pojemniki (misy, tace), kosze, drewniane skarbonki, itp. ${ }^{88}$. Opisy podobnych przedmiotów można znaleźć w pracach Czekanowskiego.

\section{Pigmeje w wyobrażeniach ludzi Zachodu}

Analizując zmiany w kulturze Pigmejów nie sposób pominąc ich wizyt w Europie. Miały one wpływ nie tylko na kulturę samych Pigmejów, ale także - a może przede wszystkim - na kulturę Zachodu. Na początku XX w. popularne były tzw. „ludzkie zoo". Z odległych krajów sprowadzano przedstawicieli „egzotycznych” kultur, aby Europejczyk mógł ich osobiście zobaczyć. Dalekie podróże były wtedy czasochłonne, a przede wszystkim kosztowne. Dlatego prościej było sprowadzić grupkę ludzi do dużego miasta europejskiego, gdzie była oglądana przez szerokie rzesze publiczności, niż zainteresowanych wywozić w odległe kraje ${ }^{89}$. Podobne zjawisko zaobserwował Czekanowski w przypadku Pigmejów, którzy byli wywożeni do Europy. 16 stycznia 1908 r. spotkał powracającego z Europy pułkownika Harrisona.

Objeżdżał nasz kontynent z sześciu Pigmejami, których przy sposobności tego objazdu badał w Berlinie mój szef, profesor v. Luschan. Miał szczęście z Pigmejami zetknąc się wcześniej w Berlinie niż ja w Afryce Środkowej. Wyobrażam sobie, jak zacny Geheimrat triumfuje! Celem europejskiej podróży emerytowanego pułkownika był oczywiście przede wszystkim Londyn. Dotarł nawet do buckinghamskiego pałacu, gdzie pokazywał swoich pupilów rodzinie królewskiej. Z tego był najbardziej dumny. Obecnie wybierał się do lasów dorzecza Ituri, na terytorium Państwa Niezależnego, aby małych i jakoby całkiem dobrowolnych turystów odstawić do ich miejsc rodzinnych - jak powiadał. (...) Robili wrażenie nieszczęśliwych, zastraszonych zwierzątek. W kwieci-

${ }^{87}$ Takie same ilustracje - nie tylko instrumentów muzycznych - można znaleźć w Forschungen im Nil-Kongo-Zwischengebiet [1924: 384, 385, 435] oraz polskim wydaniu W głąb lasów Aruwimi.

88 J. Czekanowski, Forschungen ... op. cit., ss. 387-390.

89 Nie była to tylko europejska specyfika, podobne przedsięwzięcia organizowali Japończycy. Wacław Sieroszewski wspomina pewnego Ajna, którego spotkał w czasie wyprawy (wspólnie z Bronisławem Piłsudskim) na Hokkaido, celem jej było prowadzenie badań wśród Ajnów. Spotkany przez nich Ajn mówił, że pewien „Japończyk skusił go obietnicą wielkich zarobków, więc zgodził się udać wraz z żoną i paroma sąsiadami na wystawę w Osaka, gdzie mieli 'udawać' wieś ajnoską i pokazywać "święto niedźwiedzie"” (W. Sieroszewski, Wśród kosmatych ludzi, Warszawa: Wiedza Powszechna 1957, s. 26). 
stych szatach wyglądali jak żałosne małpikróliki. Nie wydawało się, by darzyli swojego opiekuna jakimś szczególnym zaufaniem. Był czymś w rodzaju impresaria otoczonego tresowanymi zwierzętami. Zwyczajem praktykowanym w panoptikach, w których zapewne ze swoją ,trupą” występował, tytułował Pigmejkę - princess ${ }^{90}$.

Wielki wpływ na wyobrażenia o Pigmejach wśród ludzi Zachodu miały publikacje ukazujące się już od końca XIX w. Współcześnie, dochodzą do tego różnego rodzaju filmy czy programy telewizyjne. W 1933 r. w rejonie rzeki Semliki przebywał wspomniany już Kazimierz Nowak. Spotkanych Pigmejów nazywał „małoludami Mambuti”, „karłami lasu podrównikowego”, a z jego opisu wynika, że ich kultura od czasów pobytu Czekanowskiego nie uległa zmianie. Pigmejów przedstawia jako prawdziwych leśnych ludzi, którzy rodzą się w puszczy, która ich żywi i jest także miejscem ich śmierci. „Prawie nadzy, mając zwierzyny i grzybów las pełen, nie potrzebują jakichkolwiek pieniędzy. (...) Mieszkają w małych grupkach, po trzydzieści do sześćdziesięciu osób. Polują wspólnie, zdobycz dzieląc między wszystkich"91.

Śledząc polską młodzieżową XX wieczną literaturę przygodową, można odnieść wrażenie, że badania profesora Czekanowskiego w Afryce miały na nią pewien wpływ. Alfred Szklarski w książkach o przygodach Tomka Wilmowskiego, we fragmentach poświęconych wyprawie do Afryki, część trasy łowców dzikich zwierząt wiedzie „szlakiem Czekanowskiego”. Bohaterowie Szklarskiego odwiedzają między innymi Katwe i Beni. Katwe opisuje jako małą osadę murzyńską, leżącą nad Jez. Edwarda. Nad jego brzegami bohaterowie książki widzieli „lękliwe flamingi", które dzisiaj - obok salin - są atrakcją turystyczną tej małej miejscowości ${ }^{92}$.

W okolicach Beni, które Czekanowski odwiedził 8-10 lutego 1908 r. autor lokalizuje spotkanie bohaterów z ,leśnymi ludźmi” (rozdziały XVI, XVIII i XIX) jak nazywa Pigmejów. Szklarski jest wyraźnie nimi zaintrygowany, opisuje ,afrykańskich karłów”, ich życie w „czeluściach dżungli” traktując spotkanie łowców dzikich zwierząt z nimi jako kolejną egzotyczną przygodę bohaterów opowieści. Przedstawia Pigmejów jako wspaniałych przewodników po afrykańskiej dżungli. „Znali ukryte w gąszczu ścieżki, jak i przejścia przez moczary, a niedostępna oraz groźna dla innych dżungla otwierała przed nimi swe mroczne, tajemnicze podwoje"93. Podobnie uważał Czekanowski pisząc: „Batwa uważali puszczę za swoje niezawisłe królestwo. Uznawali to widać i rolnicy ... skoro tak się już utarło, że spotkany w lesie rolnik bez słowa sprzeciwu dawał się doszczętnie obrabo-

90 J. Czekanowski, $W$ głąb ... op. cit., s. 195-196.

${ }^{91}$ K. Nowak, Rowerem ... op. cit., s. 123.

92 A. Szklarski, Przygody Tomka na Czarnym Lądzie, Katowice: Wydawnictwo Śląsk 1977, s. 134.

93 Ibidem, s. 165. 
wać. Chłopi byli przeświadczeni - zresztą najsłuszniej - że bez cichej zgody tych leśnych koboldów ${ }^{94}$ nikt żywy nie wyjdzie z puszczy”95.

\section{Zakończenie}

Popularyzatorzy „egzotycznych kultur” (podróżnicy, dziennikarze, turyści), a także część etnologów często apeluje o ratowanie ginących kultur. Najczęściej ilustrowane jest to przykładem zaniku wielu elementów kultury duchowej (wierzenia, folklor, język), kultura materialna wydaje się być mniej atrakcyjna w tym kontekście. W „Rzeczpospolitej” ukazał się artykuł, pokazujący ,jaki procent języków wyginie w ciągu 100 lat - w porównaniu z ilością gatunków zwierząt”. Czytelnik może dowiedzieć się, że wyginie 5\% ryb, 8\% roślin, 11\% ptaków, 18\% ssaków i $40 \%$ języków ${ }^{96}$. Można stąd wnioskować, że małe ludy są najbardziej zagrożonymi na Ziemi. Analizując procesy przemian, które dotykają tradycyjnych kultur, szczególnie ludów o niewielkiej liczebności, zauważam proces daleko idących przemian niejednokrotnie zmierzających w stronę całkowitego wchłonięcia przez potężniejszych sąsiadów. Sądzę, że procesy te przebiegały od czasów, kiedy zaczęły się ze sobą ścierać większe i mniejsze grupy ludzkie, czyli „od zarania dziejów”. Przykładem mogą być zmiany w kulturze Pigmejów oraz zanik języków przez nich używanych. Proces przemian zachodzących w przeszłości czy też współcześnie jest nieunikniony. Tradycyjne kultury będą ulegały przemianom, będą wchłaniane przez większe, silniejsze, a wiele z nich przestanie istnieć. Zmiany są naturalnym zjawiskiem $w$ istniejących kulturach, nie zmieniają się tylko kultury wymarłe. W przypadku kultury ludów zbieracko-łowieckich problem jest poważniejszy, gdyż została ona usunięta siłą z naturalnego środowiska.

Obserwując proces przemian od czasów opisu Jana Czekanowskiego, po aktualne badania można zauważyć, że wiele zmian było przez Pigmejów akceptowanych a nawet pożądanych (I połowa XX w.). Później sytuacja uległa zmianie (II poł. XX w.), kiedy zmuszono ich do opuszczenia naturalnych siedzib. Proces ten jest groźny nie dlatego, że generuje poważne komplikacje w ich kulturze, ale dlatego, że zagraża egzystencji wielu ludów zbieracko-łowieckich, przykładem mogą być Ikowie z Ugandy. Tu już nie chodzi o „gwałt na kulturze”, ale o krzywdę ludzi. Zwracał na to uwagę Bronisław Piłsudski prowadzący badania na Sachalinie na przełomie XIX i XX w., gdy ucząc rolnictwa pomagał autochtonom przystosować się do nieuniknionego procesu zachodzących zmian. Być może podobna idea przeświecała P. Schebeście, kiedy proponował Pigmejom, w latach 30. XX wieku zakładanie plantacji bananów. Doprowadziłoby to do poważnych zmian w ich gospodarce, ale

${ }^{94}$ Kobold, postać pochodząca z folkloru niemieckiego oznaczająca karła, duszka pilnującego podziemnych skarbów.

95 J. Czekanowski, W głą ...op. cit., s. 44.

${ }^{96}$ I. Redlińska, Zniknie kilka tysięcy języków, „Rzeczpospolita” 21.09.2007, s. A12. 
uchroniłoby ich jako grupę będącą, szczególnie w sferze duchowej, depozytariuszem kultury minionych pokoleń. Podobnego zabiegu dokonał w latach 40. XX w. francuski etnolog Marcel Griaule, który zaczął budować na terenach zamieszkałych przez Dogonów (Republika Mali) zapory wodne i popularyzować hodowlę cebuli szalotki. Zabieg ten $\mathrm{z}$ jednej strony spowodował zmiany $\mathrm{w}$ ich gospodarce oraz w strukturze społecznej ${ }^{97}$, z drugiej zaś podwyższył poziom ich życia.

Wspomniani popularyzatorzy, tak ci z wieku XX jak współcześni, mają poczucie swego rodzaju misji ratowania zagrożonych kultur. Mając jednak na uwadze powyższe spostrzeżenia należy zadać zasadnicze pytanie: co jest istotniejsze? Zachowanie „ginących” kultur w niezmienionej postaci, tak aby pasowały do romantycznego, zachodniego punktu widzenia, i abyśmy mogli podziwiać bogactwo ich nieskażonej, tradycyjnej kultury? Czy też chronić te małe grupy, traktowane jako zbiór jednostek, których kultura się zmienia, ewoluuje? Nawet, jeśli zmierza w stronę wchłonięcia, zaniku, ale pod warunkiem, że sami do tego zmierzają a nie są zmuszani? Pierwsza możliwość dotyczy sytuacji grupy, a właściwie naszego wyobrażenia o tym jak powinno wyglądać życie „ginącej kultury”. Druga opcja zwraca uwagę na człowieka (będącego wartością nadrzędną) jako jednostkę tworzącą wspólnotę, a nie na grupę (lud, plemię) składającą się z bezimiennych osobników. Odpowiedź na te pytania jest trudna i skomplikowana, niewątpliwie wykracza poza granice niniejszego artykułu.

Dr Lucjan Buchalik, etnolog afrykanista, muzealnik, dyrektor Muzeum Miejskiego w Żorach (od 2003). Stworzył od podstaw kolekcję zbiorów pozaeuropejskich w Żorach (Afryka Zachodnia, Środkowa, Daleki Wschód). W latach 1998-2007 prowadził badania nad pokrewieństwem żartów między ludami Dogon (Mali) i Kurumba (Burkina Faso). W latach 2010-2017 prowadził badania z zakresu antropologii turystyki pt. „Społeczności tradycyjne Afryki wobec współczesnych przemian. „Turystyczny raj” czy „smutek tropików"? Na przykładzie Dogonów z Mali i Somba z Beninu i Togo (Afryka Zachodnia)". Podsumowaniem długoletnich badań terenowych są książki: Kolorowy $\mathrm{Sa}$ hel (2000), Niewolnicy kobiet, czyli pokrewieństwo żartów Dogonów i Kurumba (2009), Dogon ya gali. Dawny świat Dogonów (2011) oraz kilkadziesiąt artykułów.

${ }^{97}$ Dogonowie zamieszkują urwiska skalne (Falezy Bandiagary), często byli atakowani przez nieprzyjaciół. Z tego też powodu bezpieczniejsze, wyżej położone obszary wioski były zamieszkałe przez osoby wyżej sytuowane w hierarchii społecznej. Po wybudowaniu zapór osoby o niższym statusie społecznym miały łatwiejszy dostęp do nawodnionych pól i szybciej się bogaciły. Pojawił się pewien dysonans społeczny osoby pełniące ważne funkcje społeczne były biedniejsze od osób należących do niższych warstw społecznych. Zjawisko to wymaga dalszych badań. 


\section{Bibliografia:}

Amselle, Jean-Loup, Ethnies et espaces: pour une anthropologie topologique, (w:) JeanLoup Amsel, Elikia M'Bokolo (red.), Au coeur de l'ethnie: ethnie, tribalisme et État en Afrique. Paris 1999, s. 11-48.

B.a., Semuliki National Park. The True Birders'Haven, Kampala, b.d.

Barth, Frederik, Balinese Worlds, Chicago: University of Chicago Press 1993.

Chaillu, Paul du, L'Afrique Sauvage, Paris 1868.

Czekanowski, Jan, Verwandtschaaftsbeziehungen der zentralafrikanischen Pygmäen. „Korrespondenz-Blatt der Deutschen Gesellscaft für Anthropologie, Ethnologie und Urgeschichte", nr 9/12, 1910.

Czekanowski, Jan, Forschungen im Nil-Kongo-Zwischengebiet, t. II Ethnografie. Uele/ Ituri/ Nil-Länder, Lepzig: Klinkhardt \& Biermann 1924.

Czekanowski, Jan, W głą lasów Aruwimi, Wrocław: Polskie Towarzystwo Ludoznawcze 1958.

Czekanowski, Jan, Struktura etniczna Afryki a nawarstwienia najmłodsze, „Lud” t. 45, 1960, ss. 13-34.

Czekanowski, Jan, Dziennik podróży afrykańskiej, Warszawa: Polskie Towarzystwo Afrykanistyczne 2014.

Eriksen, Thomas Hylland, Małe miejsca, wielkie sprawy. Wprowadzenie do antropologii społecznej i kulturowej, tłum. Joanna Wołyńska, Warszawa: Oficyna Wydawnicza Wolumen 2009.

Henzel, Tadeusz, Pigmeje Centralno-Afrykańscy, Lwów: Towarzystwo Naukowe 1934.

Kosibowicz, Edward, Problem ludów pigmejskich, Kraków: Wydawnictwo Księży Jezuitów 1927.

Leszczyński, Adam, Spieszmy się stuchać mlasków, „Gazeta Wyborcza” 25.07.2014.

Lula, Wojciech, Nowa droga w edukacji pigmejskich dzieci, „Wrota Afryki”, nr 60, czerwiec-sierpień 2016, s. 6-7.

Łapott, Jacek, Wyprawa Naukowa SAHEL'87 - sprawozdanie z przebiegu i wyników dziatalności etnologicznej ekspedycji do Afryki, „Materiały Zachodnio-Pomorskie” t. 37, 1991, s. 281-311.

Łysik, Stefan, Pigmeje afrykańscy i zagadnienie ich języka, „Lud” t. 45, 1960, ss. 35-69.

Łysik, Stefan, Pawet Schebesta - pionierski badacz Pigmejów (1887-1967), „Lud” t. 53, 1969, ss. 251-272.

Majewicz, Alfred F., Dzieje i wierzenia Ajnów, Poznań: CIA-Books-SVARO, Ltd. 1991.

Maurice, Albert-Marie, Atakora, Otiau Otammari Osuri. Peuple du Nord Bénin, Paris: Académie des Sciences d'Outre-Mer 1950.

Mercier, Paul, Tradition changement historie: les 'Somba' du Dahomey septentrional, Paris: Éd. Anthropos, 1968.

Nowak, Kazimierz, Rowerem i pieszo przez Czarny Ląd. Listy z podróży afrykańskiej z lat 1931-1936, Poznań: SORUS S.C. Wydawnictwo i Drukarnia 2008.

Quatrefages, Armand de, Les Pygmées, Paris 1887.

Redlińska, Izabela, Zniknie kilka tysięcy języków, "Rzeczpospolita" 21.09.2007, s. A12.

Schweeger-Hefel, Anne-Marie, Staude Wilhelm, Die Kurumba von Lurum, Wien 1972.

Schweinfurth, Georg, Im Herzen von Afrika. Reisen und Entdeckungen im zentralen Aequatorial-Afrika 1868-1871, t. 2, Leipzig 1874. 
Sieroszewski, Wacław, Wśród kosmatych ludzi, Warszawa: Wiedza Powszechna 1957.

Szklarski, Alfred, Przygody Tomka na Czarnym Lązie, Katowice: Wydawnictwo Śląsk 1977.

Turnbull, Colin M., Leśni ludzie, Warszawa: Iskry 1967.

Turnbull, Colin M., Ikowie ludzie gór, Warszawa: Państwowy Instytut Wydawniczy 1980.

Turnbull, Colin M., The Mbuti Pygmies: Adaptation and Change, New York: Holt, Rinehart \& Winston 1983.

Turski, Roman, Żyłem wśród Pigmejów, „Poznaj Świat” nr 4, 1970, ss. 33-35.

Wikan, Unni, Managing Turbulent Hearts, Chicago: University of Chicago 1992.

\section{Informatorzy:}

Ben, lat $\sim 35$, przewodnik turystyczny, chrześcijanin, mieszkaniec Rubuguri, Muchiga.

Cherotwo, lat $\sim 35$, przewodnik Sipi Falls Tour, chrześcijanin, Sapin.

Issa, lat 30, przewodnik w Muzeum, muzułmanin, mieszkaniec Rubuguri.

John, lat $\sim 60$, rolnik, chrześcijanin, mieszkaniec Bwindi, Batwa.

Nora, 78 lat, głowa rodziny, chrześcijanka, mieszkanka Bwindi, Batwa.

Victor, 30 lat, przewodnik turystyczny, mieszkaniec Rubuguru, Muchiga.

\section{Strony internetowe:}

https://en.wikipedia.org/wiki/Nyundo,_Rubavu (29.06.2016).

http://kwekudee-tripdownmemorylane.blogspot.com/2013/03/batwa-people-one-of-firstpeople-on.html (dostęp 04.08.2014).

https://pl.wikipedia.org/wiki/Paul_Schebesta (29.07.2016).

http://wiadomosci.gazeta.pl/wiadomosci/1,114871,13840706,Rzad_wyrzuca_60_tys_Ma-

sajow_z_ich_ziemi_Chce_tam.html (02.05.2013).

http://pl.wikipedia.org/wiki/Nieprzenikniony_Las_Bwindi (04.08.2014). 